\title{
SALIVARY PARAMETERS AND TEETH EROSIONS IN PATIENTS WITH GASTROESOPHAGEAL REFLUX DISEASE
}

\author{
Maria Carolina Canteras Scarillo Falotico CORRÊA 1 , Mauro Masson LERCO², \\ Maria de Lourdes Ribeiro de Sousa da CUNHA ${ }^{3}$ and \\ Maria Aparecida Coelho de Arruda HENRY ${ }^{4}$
}

\begin{abstract}
Context - In the gastroesophageal reflux disease (GERD), a highly prevalent digestive disorder, gastric content may return to the esophagus and reach the mouth, thus leading to a small number of carious lesions and high incidence of dental erosion. Since saliva plays a major role in oral homeostasis, evaluating salivary parameters is necessary in attempting to explain such outcome. Objectives - This study aimed at analyzing salivary parameters (salivary flow, $\mathrm{pH}$ and buffering capacity), bacterial count, caries index and dental erosion in patients with GERD. Materials - Sixty patients were studied, and of these, 30 had GERD (group 1), and 30 were controls (group 2). Gastroesophageal reflux disease diagnosis confirmation was achieved by means of endoscopy, manometry and $\mathrm{pH}$ metric esophageal monitoring. The above mentioned salivary parameters were evaluated in patients from groups 1 and 2. Results - The number of erosions in patients with GERD (group 1) was larger than in controls $(P<0.001)$. The number of carious teeth was smaller in group 1 than in group $2(P<0.001)$. Salivary flow (non-stimulated and stimulated) and $\mathrm{pH}$ did not show differences between the 2 groups $(P=0.49 ; P=0.80$ and $P=0.85$, respectively). Salivary buffering capacity in patients with GERD showed lower values in controls $(P=0.018)$. The number of bacteria (Lactobacilli and Streptococci) was smaller in patients with gastroesophageal reflux disease than in controls $(P=0.0067$ and $P=0.0017$, respectively). Conclusion - It was concluded that the large number of erosions must be a result of GERD patients reduced salivary buffering capacity. The reduced number of caries of patients in group 1 can be explained by the low prevalence of bacteria (Lactobacilli and Streptococci), observed in the saliva of patients with chronic reflux.
\end{abstract}

HEADINGS - Saliva. Tooth erosion. Dental caries. Gastroesophageal reflux.

\section{INTRODUCTION}

The gastroesophageal reflux disease (GERD) is a condition that develops when gastric content passes to the esophagus and causes the onset of annoying symptoms and/or complications ${ }^{(17)}$. It is a disease of great medical and social importance due to its increasing incidence and long-lasting symptoms, which hinder patients quality of life ${ }^{(5,20)}$.

The oral lesions resulting from GERD are not usually noticed by patients, physicians or dentists until they cause significant damage. They may range from pruritus and burning on the oral mucosa, tooth sensitivity, aphthae, sour taste, decrease in the vertical dimension of occlusion to irreversible damage such as dental erosion, which can be increased by friction or abrasion ${ }^{(19)}$.
Studies on the oral health of patients with chronic reflux have shown a prevalence of dental erosion and a small number of caries in individuals with GERD as compared to control groups ${ }^{(3,4,10)}$.

Silva et al. ${ }^{(23)}$ studied patients with GERD and reported that saliva is an important dental erosion modifier. However, they did not relate the reflux disease to the presence of carious lesions, but only to microscopic alterations on the palatal mucosa.

Saliva is one of the major elements responsible for homeostasis in the oral cavity and in the digestive tract. Alterations in both $\mathrm{pH}$ and salivary volume were found in patients with GERD $^{(9)}$. In addition to playing a vital role in maintaining healthy mouth tissues, saliva has several other functions in the oral cavity; therefore, its reduction may cause difficulties in speaking and eating, dysphagia, dysgeusia, oral hygiene deficiency, traumas,

\footnotetext{
Declared conflict of interest of all authors: none.

General Surgery Bases in the Department of Surgery and Orthopedy, Botucatu School of Medicine, State University of São Paulo (UNESP) ${ }^{2}$ Department of Surgery and Orthopedy Botucatu School of Medicine, UNESP. ${ }^{3}$ Department of Microbiology, Biosciences Institute, UNESP. ${ }^{4}$ Department of Surgery and Orthopedy, Botucatu School of Medicine, UNESP, Botucatu, SP, Brazil.

Correspondence: Dr. Maria Carolina C.S.F. Corrêa - Departamento de Cirurgia e Ortopedia da Faculdade de Medicina de Botucatu, Distrito de Rubião Jr. s/n - 18618-
} 970 - Botucatu, SP, Brazil. E-mail: mcarolcorrea@hotmail.com or rhenry@ibb.unesp.br 
ulcers and the feeling of mucosal burning, candidiasis, caries and susceptibility to dental erosion. The buffering capacity of saliva keeps the mouth's $\mathrm{pH}$ so as to ensure the integrity of tooth structure and inhibit the acid from bacterial plaque. Salivary flow reduction will cause the loss of certain salivary functions, allowing for the development of bacterial plaque, high caries activity and smaller salivary buffering capacity.

The dissolution of dental structure in caries and dental erosion occurs when saliva $\mathrm{pH}$ reaches a lower value than 5.5. This is "critical oral $\mathrm{pH}$ ", under which dental tissue demineralization initiates ${ }^{(15)}$.

Dental caries is an infectious, contagious, and incurable disease that affects $95 \%$ of the world population in different ways for each individual. Caries initiation requires the interaction of several factors, such as the host, microflora, cariogenic substrate and time for the disease's development. According to Krasse ${ }^{(13)}$, caries activity is inversely proportional to saliva buffering capacity and directly proportional to the presence of Streptococcus mutans. Krasse ${ }^{(13)}$ defined dental caries as a destruction located on teeth. The destruction of dental enamel, which consists of $95 \%$ hydroxyapatite, is mainly caused by the organic acids produced by the action of microorganisms that ferment carbohydrates, particularly sugars. In the dentin, such process is followed by the digestion of organic structure. The three main factors for caries development are the host, the microbiota and diet. Some microorganisms are more important in caries pathogeny, such as Streptococcus mutans, which are related to the initial phase, and Lactobacillus, whose growth produces acid and reduces oral $\mathrm{pH}$ to levels below critical $\mathrm{pH}$ when microorganisms have adhered to the tooth. Reduction in saliva $\mathrm{pH}$ and alterations in its buffering capacity and viscosity directly influence the severity of erosive lesions.

This study aimed at evaluating the results of saliva tests (non-stimulated salivary flow, stimulated salivary flow, $\mathrm{pH}$, salivary buffering capacity), caries and erosion index and bacterial count (Streptococcus mutans and Lactobacillus) in individuals with GERD.

\section{METHODS}

In this prospective study, 60 patients cared by Department of Surgery Orthopedy and were clinicaly evaluated. Of these, 20 were males $(33.3 \%)$ and 40 were females $(66.6 \%)$ with ages raging from 17 to 60 years, who were divided into two groups. The demographic aspects are listed in Table 1.

TABLE 1. Demographic aspects presented by patients with GERD (group 1) and controls (group 2)

\begin{tabular}{lcccc}
\hline & \multicolumn{2}{c}{ Group 1 } & \multicolumn{2}{c}{ Group 2 } \\
& $\mathbf{n}$ & $\%$ & $\mathbf{n}$ & $\%$ \\
\hline Male & 10 & 33.3 & 10 & 33.3 \\
Female & 20 & 66.6 & 20 & 66.6 \\
Minimal age (years) & 18 & & 17 & \\
Maximal age (years) & 54 & & 49 & \\
Average (years) & 33.41 & & 30.99 \\
\hline
\end{tabular}

Group 1: 30 individuals with GERD in pre operative period of laparoscopic fundoplication, cared for by the Discipline of Surgical Gastroenterology at the Department of Surgery and Orthopedy of the Botucatu School of Medicine - UNESP, Botucatu, SP, Brazil. The diagnosis of GERD was confirmed by the clinical, endoscopic, manometric and pHmetric findings. All patients presented tipical symptoms for GERD.

Group 2: 30 patients without clinical evidence of GERD, located in the infirmary in the pre operative period of inguinal hernia.

Inclusion criteria: males and females individuals aged 17 to 60 years, with at least 20 teeth. Systemic medications were systemically recorded in the questionnaire for later correlation with salivary parameters after agreement in participation in this study. The informed consent was obtained in all patients. The protocol was approved by the Ethical Committee of School of Medicine of Botucatu-UNESP (OF340-2007). Exclusion criteria: patients under 20 years old and over 60 years old; pregnant women and individuals with systemic diseases affecting esophageal motor activity and salivary flow.

The patients in group 1, 30 patients were submitted to upper digestive endoscopy, manometry and esophageal $\mathrm{pH}$-metry for GERD diagnosis confirmation, in addition to a questionnaire containing questions concerning risk factors for the reflux disease (pirosis, regurgitation and alimentary customs), a detailed clinical oral examination, salivary tests and saliva bacterium count. The individuals in group 2 were submitted to clinical oral examination and salivary tests and answered a questionnaire. The endoscopic, manometric and $\mathrm{pH}$-metric esophageal tests were not performed for this group as recommended by the Ethics Committee.

After a 12-hour fasting period, the patients were endoscopically evaluated by using an endoscopic video (GIF-Olympus). This test enabled the analysis of the esophageal mucosa, cardia competence and presence of hiatal hernia. The endoscopic appoints informations concerning the cardia capacity, by the retroversion maneuner. The Savary-Miller and Los Angeles classifications have the impropriety of not considering the light disorders (edema, eritema and disappearance of the gastroesophageal junction).

After the performance of esophageal manometry, the methodology previously standardized in the laboratory was used, according the pull through technique with evaluation of the following attributes: pressure amplitude in the lower and upper esophageal sphincters and motor activity of the esophageal body. For esophageal manometry, a light lumen low compliance infused system with computerized data acquisition and analysis was employed. We consider normal values when LES pressure were above $10.0 \mathrm{~mm} \mathrm{Hg}$.

Esophageal pHmetry was performed in all group 1 patients. The disposable catheter in our laboratory at that time had one sensor. The pHmetric study was performed according the technique standardized in our laboratory ${ }^{(12)}$, considering the reflux episode when the esophageal $\mathrm{pH}$ was lower than 4 units $^{(12)}$. 
This test enables the analysis of various parameters, of which the most important are the percentage of time (of the 24 hours) in which the esophagus showed values below 4 units and De Meester score.

All the individuals (groups 1 and 2) were initially submitted to a detailed questionnaire with questions concerning risk factors for GERD, diet, medication and oral hygiene. The clinical oral evaluation performed using the clinical mirror and convenient catheter made it possible to evaluate the dental caries index and erosion ${ }^{(4)}$. Next, the gingiva was probed by a millimeter probe recommended by the Health World Organization, for analysing the depth of the gingiva lesions, and the erosions were evaluated according to Eccles and Jenkins classification ${ }^{(7,8)}$. This exam was performed by a dental surgeon, without knowledge of patients with GERD.

Total saliva was collected for 5 minutes for stimulated by the chewing of a small fragment $(1 \mathrm{~cm})$ of a strangling-stick, and non-stimulated, at rest with the half open mouth allowing the salivary flow. The values were evaluated by the gravimetric method proposed by Lussi ${ }^{(16)}$. The stimuled flow was obtained after chewing a strangling-stick during 5 minutes.

Salivary $\mathrm{pH}$ and buffering capacity were measured by a portable $\mathrm{pHmeter}$.

Buffering capacity is the salivary capacity to neutralize weak acids produced in saliva and on bacterial plaque, which lead to the dissolution of dental mineral tissues, that is, resistance against $\mathrm{pH}$ alterations. The method used is that preconized by Lussi ${ }^{(16)}$.

The saliva samples were taken to the laboratory and seeded for at least 1 hour after collection and properly protected in order to prevent bacterial proliferation. After homogenization and dilution in autoclaved yeast extract, 100 microliters were seeded on each dish containing selective medium for $S$. mutans and Lactobacillus ${ }^{(1)}$.

\section{Statistical analysis}

The Chi-square or Fisher's exact tests were used for group comparison. Student's $t$ test for independent populations was utilized for the quantitative variables. The level of significance adopted was $5 \%$.

\section{RESULTS}

Of the 30 patients in group 1, $20(66 \%)$ showed non-erosive GERD, and 10 patients showed level-1 and level-2 reflux esophagitis according to the Savary and Miller classification $^{(22)}$. Hiatal hernia was found in $17(56.6 \%)$, with a mean size of $3.7 \mathrm{~cm}$. By the retroversion maneuver, cardia incompetence was observed in 28 patients in this group $(93.3 \%)$. The diagnosis of GERD was performed after the analysis of the clinical, endoscopic, manometric and $\mathrm{pHmetric}$ findings.

The mean pressure in the lower esophageal sphincter was of $10.75 \pm 2.42 \mathrm{~mm} \mathrm{Hg}$, and in the upper sphincter, it was $75.24 \pm 28.08 \mathrm{~mm} \mathrm{Hg}$. No disorder was observed for esophageal body motor activity in any of the patients with GERD (group 1).

Twenty-four-hour esophageal $\mathrm{pH}$-metry enabled the analysis of several parameters, of which the most significant were the percentage of time during which esophageal $\mathrm{pH}$ was below 4 units, with a mean of $7.03 \pm 5.49 \%$ and the DeMeester score, with a mean of $27.55 \pm 18.98$. In seven $(23 \%)$ of the patients in group 1, such score was normal, and the diagnosis of GERD was confirmed by the clinical, endoscopic and manometric findings. The mean number of teeth with dental erosion for patients with GERD was of $5.22 \pm 2.52$, and in controls, it was of $0.06 \pm 0.36(P<0.001)$ (Table 2).

Forty-one carious teeth were observed in patients in group 1 (mean of $3.63 \pm 0.70$ ) and 156 for controls, with a mean of $5.77 \pm 4.39(P<0.001)$.

The mean non-stimulated salivary flow for group 1 was of $0.26 \pm 0.18 \mathrm{~mL} / \mathrm{min}$, and for group 2 , it was of $0.23 \pm$ $0.13 \mathrm{~mL} / \mathrm{min}(P=0.49)$. As regards the stimulated salivary flow, the mean value for group 1 was $0.75 \pm 0.29 \mathrm{~mL} / \mathrm{min}$ and $0.78 \pm 0.52 \mathrm{~mL} / \mathrm{min}$ for group $2(P=0.80)$. Saliva $\mathrm{pH}$ in both groups did not show significant difference $(P=0.85)$. Buffering capacity was smaller in group 1 , than in group 2 (3.77 $\pm 0.9 \times 3.21 \pm 0,7 ; P=0.018)$.

As concerns the number of bacterial colonies found in saliva, lower values were observed in patients with reflux (group 1) than in controls, both for the evaluation

TABLE 2. Mean and standard desviation for the analyzed variables according to groups

\begin{tabular}{|c|c|c|c|c|c|}
\hline \multirow[b]{3}{*}{ Variables } & \multicolumn{4}{|c|}{ Group } & \multirow{3}{*}{$P$ value } \\
\hline & \multicolumn{2}{|c|}{ G1 } & \multicolumn{2}{|c|}{ G2 } & \\
\hline & Mean & SD & Mean & SD & \\
\hline Number of level-1 erosions & 3.76 & 2.13 & 0.13 & 0.51 & $<0.001$ \\
\hline Number of level-2 erosions & 0.83 & 1.58 & 0.00 & 0.00 & 0.005 \\
\hline Number of level-3 erosions & 0.10 & 0.55 & 0.00 & 0.00 & 0.32 \\
\hline Total number of erosions & 4.70 & 2.52 & 0.06 & 0.36 & $<0.001$ \\
\hline Number of carious teeth & 1.3 & 2.5 & 5.2 & 1.3 & $<0.001$ \\
\hline Non-stimulated salivary flow $\mathrm{mL} / \mathrm{min}$ & 0.26 & 0.18 & 0.23 & 0.13 & 0.49 \\
\hline Stimulated salivary flow $\mathrm{mL} / \mathrm{min}$ & 0.75 & 0.29 & 0.78 & 0.52 & 0.80 \\
\hline $\mathrm{pH}$ salivary & 7.1 & 0.4 & 7.0 & 0.4 & 0.85 \\
\hline buffering capacity & 3,2 & 0,7 & 3,7 & 0,9 & 0,018 \\
\hline
\end{tabular}


of Lactobacilli $(P=0.0067)$ and for that of Streptococci $(P=0.0017)($ Table 3$)$.

TABLE 3. Confluent type count (Petri dish with more than 300 colonies) of Streptococci and Lactobacilli in saliva

\begin{tabular}{lcc}
\hline Group & Saliva Lactobacilli & Saliva Streptococci \\
\hline 1 & 01 & 05 \\
2 & 10 & 21 \\
\hline$P=0.0067 P=0.0017$ & &
\end{tabular}

\section{DISCUSSION}

Among the individuals with reflux (group 1), 66.6\% were females, which is in agreement with previously published articles, as a higher incidence of GERD in women has been reported by many authors ${ }^{(17)}$. In group 2 (control), the distribution of patients in relation to gender was similar to that in group 1, with a higher percentage of females $(66.6 \%)$.

The mean age of patients in group 1 was 33.41 years, which was lower than that reported by Mota et al. ${ }^{(18)}$. The patient's young age can be explained by the fact that one of factors for their inclusion in this study was the presence of teeth in reasonably good conditions, a fact that was not observed in older individuals.

Among the oral lesions observed in individuals with GERD, the most evident was dental erosion, with a higher incidence in group 1 than in controls $(P<0.001)$, a similar result to that observed by various authors ${ }^{(3,4)}$.

The classification used for the patients in this study was that proposed by Eccles and Jenkins ${ }^{(7)}$. The most frequently found erosions were levels 1 and 2 , which were more numerous in individuals with GERD than in controls $(P<0.001)$ (Table 1).

In this study, it was observed that the number of caries was smaller in patients with GERD than in controls $(P<0.001$ - Table 1). Our results are in agreement with those reported by Cazzonato et al. ${ }^{(3)}$, Corrêa et al. ${ }^{(4)}$ and Ersin et al. ${ }^{(10)}$, who reported an inverse relation between caries and gastroesophageal reflux. However, Linnett et al. ${ }^{(14)}$ report that individuals with reflux have more erosions and dental caries than the control group. Silva et al. ${ }^{(23)}$ did not find a relation between GERD and the presence of caries.

In patients in group 2 (control), non-stimulated salivary flow showed a mean value of $0,23 \pm 0.13 \mathrm{~mL} / \mathrm{min}$, which was considered to be normal ${ }^{(16,21)}$. In this group, the stimulated salivary flow observed was of $0.78 \pm 0.52 \mathrm{~mL} / \mathrm{min}$, characterized as a small salivary flow, according Lussi ${ }^{(16)}$ and Raphael et al. ${ }^{(21)}$.

In individuals with pathological gastroesophageal reflux (group 1), non-stimulated salivary flow showed a mean value of $0.26 \pm 0.18 \mathrm{~mL} / \mathrm{min}$, and stimulated flow showed a mean of $0.75 \pm 0.29 \mathrm{~mL} / \mathrm{min}$.

Statistical analysis (Table 2) showed that there was no difference between the two groups as regards the non-stimulated $(P=0.49)$ or stimulated $(P=0.80)$ salivary flow.

This result does not explain the caries found in controls or their relative absence in individuals with reflux $(P<0.001$ - Table 2), in addition to being in disagreement with several authors ${ }^{(2,3,6)}$.
In patients with GERD (Group 1), salivary $\mathrm{pH}$ ranged from 6.45 to 7.86 units. In the controls, the extreme values observed were 6.47 and 8.69 units (mean of $7.0 \pm 0.4$ ). The statistical analysis did not show difference between the two groups $(P=0.85)$ (Table 2$)$.

The result observed in our study disagrees with that reported by Ecley and $\operatorname{Costa}^{(9)}$. Those authors reported a positive association between GERD and salivary $\mathrm{pH}$ alterations, thus suggesting that its measurement can be used for diagnosing acid laryngopharyngeal reflux. Such test can be easily performed and could replace prolonged esophageal pHmetry using a pH microelectrode.

Salivary buffering capacity was evaluated in 60 patients in this study. In the patients with reflux, salivary buffering capacity ranged from 2.42 to 4.27 units, with a mean of 3.2 \pm 0.7 units, and in controls, the mean ranged was $3.7 \pm 0.9$ units, with extreme values of 2.18 and 6.40. As concerns the means representing low buffering capacity ${ }^{(16)}$, the statistical analysis showed that, in patients in group 1 (GERD), salivary buffering capacity was smaller than in controls $(P=0.018)$. This result can explain the high rate of dental erosions in this group as compared to controls $(P<0.001)$.

In this study, it was observed that the number of caries was much smaller in patients with GERD than in controls $(P<0.001)$, thus confirming the findings of our previous study ${ }^{(4)}$, a fact that disagrees with the study by Ersin et al..$^{(10)}$, who reported that children with GERD had a significantly higher rate of caries and salivary microorganisms than controls. After seeding the saliva in appropriate culture media, it was observed that the confluent type count (more than 300 bacterial colonies) was of one Lactobacilli count in patients in group 1 and of $10 \mathrm{in}$ controls, thus showing a reduced number of Lactobacilli in patients with GERD $(P=0.0067)$. As concerns Streptococci, a significant difference was also observed (5 $\mathrm{x} 21)(P=0.0017)$, with a smaller number of confluent colonies in patients with reflux than in controls (Table 2).

The results above are in agreement with the findings by Gábris et al. ${ }^{(11)}$, who reported that the larger the salivary microbiota, the larger the number of caries.

The results in this study lead to the following conclusions:

1. salivary flow (non-stimulated and stimulated) and salivary $\mathrm{pH}$ in patients with GERD do not differ from those observed in controls;

2. salivary buffering capacity is more reduced in individuals with GERD than in controls;

3. bacterial count (Lactobacilli and Streptococci) was more reduced in patients with GERD than in controls.

\section{ACKNOWLEDGEMENT}

To Fundação para o Desenvolvimento da UNESP FUNDUNESP, for the grant provided.

To CAPES for the fellowship provided during the research.

To the employees working at the Laboratories of Digestive Motility, Biochemistry and Microbiology of UNESP at Botucatu. 
Corrêa MCCSF, Lerco MM, Cunha MLRS, Henry MACA. Parâmetros salivares e na erosão dentária na doença do refluxo gastroesofágico. Arq Gastroenterol. 2012;49(3):214-8.

RESUMO - Contexto - Na doença do refluxo gastroesofágico, afecção digestiva de elevada prevalência, o conteúdo gástrico pode retornar ao esôfago e atingir a cavidade oral, acarretando pequeno número de lesões cariosas e elevada incidência de erosões dentais. Sendo a saliva a principal responsável pela homeostase oral, a avaliação dos parâmetros salivares é imperiosa, numa tentativa de explicar este resultado. Objetivo - O objetivo deste trabalho foi analisar os parâmetros salivares (fluxo, $\mathrm{pH}$ e capacidade tampão da saliva), contagem de bactérias, índice de cárie e erosão dental em pacientes com a doença do refluxo gastroesofágico. Métodos - Foram estudados 60 pacientes, sendo 30 com a doença do refluxo gastroesofágico (Grupo 1) e 30 controles (Grupo 2). A confirmação do diagnóstico da doença do refluxo gastroesofágico foi realizada através de exames endoscópico, manométrico e pHmétrico do esôfago. Os parâmetros salivares assinalados foram realizados nos pacientes dos grupos 1 e 2. Resultados - O número de erosões nos pacientes com a doença do refluxo gastroesofágico (grupo 1) foi mais elevado que nos controles $(P<0,001)$. O número de dentes cariados foi menor no grupo 1 do que no grupo $2(P<0,001)$. O fluxo salivar (não estimulado e estimulado) e o $\mathrm{pH}$ não apresentaram diferença nos dois grupos estudados $(P=0,49 ; P=0,80$ e $P=0,85$, respectivamente). A capacidade de tampão salivar dos pacientes com a doença do refluxo gastroesofágico apresentou valores mais baixos que nos controles $(P=0,018)$. O número de bactérias (lactobacilos e estreptococos) foi menor nos pacientes com a doença do refluxo gastroesofágico do que nos controles ( $P=0,0067$ e $P=0,0017$, respectivamente). Conclusão - Os autores concluem que o elevado número de erosões deve ser decorrente da reduzida capacidade tampão salivar dos pacientes com doença do refluxo gastroesofágico. O reduzido número de cáries dos pacientes do grupo 1 pode ser explicado pela pequena prevalência de bactérias (lactobacilos e estreptococos), observada na saliva dos pacientes refluidores crônicos.

DESCRITORES - Saliva. Erosão dentária. Cárie dentária. Refluxo gastroesofágico.

\section{REFERENCES}

1. Almeida RVD, Padilha WWN, Pereira MSV, Sampaio TPD. Avaliação de teste salivar microbiológico colorimétrico no risco à cárie dentária. Rev Bras Ciênc Saúde. 2002;6:259-68.

2. Campisi G, Lo Russo L, Di Liberto C, Di Nicola F, Butera D, Vigneri S, Compilato D, Lo Muzio L, Di Fede O. Saliva variations in gastro-oesophageal reflux disease. J Dent. 2008;36:268-71.

3. Cazzonatto Jr H, Bernasconi GCR, Pedrazzolli JR. Gastroesophageal reflux and oral lesions: is the acid that bad? GED Gastroenterol Endosc Dig. 2003;22:42-6.

4. Corrêa MC, Lerco MM, Henry MA. [Study in oral cavity alterations in patients with gastroesophageal reflux disease]. Arq Gastroenterol. 2008;45:132-6.

5. de Oliveira SS, dos Santos Ida S, da Silva JF, Machado EC. [Gastroesophageal reflux disease: prevalence and associated factors]. Arq Gastroenterol. 2005;42:116-21.

6. Di Fede O, Di Liberto C, Occhipinti G, Vigneri S, Russo LL, Fedele S, Lo Muzio L, Campisi G. Oral manifestations in patients with gastro-oesophageal reflux disease: a single-center case-control study. J Oral Pathol Med. 2008;37:336-40.

7. Eccles JD, Jenkins WG. Dental erosion and diet. J Dent. 1974;2:153-9.

8. Eccles JD. Erosion of teeth by gastric contents. Lancet. 1978;2:479.

9. Eckley CA, Costa HO. Estudo comparativo do $\mathrm{pH}$ e do volume salivar em indivíduos com laringofaringite crônica por doença do refluxo gastroesofágico antes e após tratamento. Rev Bras Otorrinolaringol. 2006;72:55-60.

10. Ersin NK, OnçağO, Tümgör G, Aydoğdu S, Hilmioğlu S. Oral and dental manifestations of gastroesophageal reflux disease in children: a preliminary study. Pediatr Dent. 2006;28:279-84.

11. Gábris K, Nagy G, Madléna M, Dénes Z, Márton S, Keszthelyi G, Bánóczy J. Associations between microbiological and salivary caries activity tests and caries experience in Hungarian adolescents. Caries Res. 1999;33:191-5.

12. Henry MA. [Continuous evaluation of esophageal $\mathrm{pH}$ for 24 hours and its use in the diagnosis of gastroesophageal reflux]. Rev Hosp Clin Fac Med S Paulo. 1984;39:203-7.
13. Krasse BO. Risco de cáries: um guia prático para avaliação e controle. São Paulo: Quintessence; 1986. 113p.

14. Linnett V, Seow WK, Connor F, Shepherd R. Oral health of children with gastro esophageal reflux disease: a controlled study. Aust Dent J. 2002;47:156-62.

15. Loesche WJ. Role of Streptococcus mutans in human dental decay. Microbiol Rev. 1986;50:353-80.

16. Lussi A. Dental erosion clinical diagnosis and case history taking. part:2. Eur J Oral Sci. 1996;104:191-8

17. Moraes-Filho J, Cecconello I, Gama-Rodrigues J, Castro L, Henry MA, Meneghelli UG, Quigley E; Brazilian Consensus Group. Brazilian consensus on gastroesophageal reflux disease: proposals for assessment, classification, and management. Am J Gastroenterol. 2002;97:241-8.

18. Mota LAA, Santos ACO, Melo Jr BC, Travassos RO, Melo MSI. Videolaringoscopia e atividade da pepsina na saliva em voluntários com sintomas sugestivos de refluxo laringofaríngeo. Arq Int Otorrinolaringol. 2008;12:89-94.

19. Myklebust S, Espelid I, Svalestad S, Tveit AB. Dental health behavior, gastroesophageal disorders and dietary habits among Norwegian recruits in 1990 and 1999. Acta Odontol Scand. 2003;61:100-4.

20. Nasi A, Michelsohn NH. Avaliação funcional do esôfago: manometria e pH metria esofágicas. São Paulo: Roca; 2001. p.39-251.

21. Raphael Jr A, Bacaltchuck BB, Jacobs ACP. Avaliação do fluxo salivar e da capacidade tampão em pacientes da clínica integrada. Rev Assoc Paul Cir Dent. 2005;59:108-12.

22. Savary M, Miller G. L'esophage. Manuel et atlas d'endoscopie. Solothurn: Gassmann; 1977.

23. Silva MAGS, Damante JH, Stipp ACM, Tolentino MM, Carlotto PR, Fleury RN. Gastroesophageal reflux disease: new oral findings. Oral Surg Oral Med Oral Pathol Oral Radiol Endod. 2001;91:301-10.

Received 10/11/2011 Accepted 19/6/2012. 